\title{
Middle East Respiratory Syndrome Coronavirus Infection Dynamics and Antibody Responses among Clinically Diverse Patients, Saudi Arabia
}

Hail M. Al-Abdely, ${ }^{1}$ Claire M. Midgley, ${ }^{1}$ Abdulrahim M. Alkhamis, Glen R. Abedi, Xiaoyan Lu,
Alison M. Binder, Khalid H. Alanazi, Azaibi Tamin, Weam M. Banjar, Sandra Lester,
Osman Abdalla, Rebecca M. Dahl, Mutaz Mohammed, Suvang Trivedi, Homoud S. Algarni,
Senthilkumar K. Sakthivel, Abdullah Algwizani, Fahad Bafaqeeh, Abdullah Alzahrani,
Ali Abraheem Alsharef, Raafat F. Alhakeem, Hani A. Aziz Jokhdar, Sameeh S. Ghazal,
Natalie J. Thornburg, Dean D. Erdman, Abdullah M. Assiri, John T. Watson, Susan I. Gerber

Middle East respiratory syndrome coronavirus (MERS-CoV) shedding and antibody responses are not fully understood, particularly in relation to underlying medical conditions, clinical manifestations, and mortality. We enrolled MERS-CoVpositive patients at a hospital in Saudi Arabia and periodically collected specimens from multiple sites for real-time reverse transcription PCR and serologic testing. We conducted interviews and chart abstractions to collect clinical, epidemiologic, and laboratory information. We found that diabetes mellitus among survivors was associated with prolonged MERS-CoV RNA detection in the respiratory tract. Among case-patients who died, development of robust neutralizing serum antibody responses during the second and third weeks of illness was not sufficient for patient recovery or virus clearance. Fever and cough among mildly ill patients typically aligned with RNA detection in the upper respiratory tract; RNA levels peaked during the first week of illness. These findings should be considered in the development of infection control policies, vaccines, and antibody therapeutics.

Author affiliations: Ministry of Health, Riyadh, Saudi Arabia (H.M. Al-Abdely, A.M. Alkhamis, K.H. Alanazi, W.M. Banjar, O. Abdalla, M. Mohammed, H.S. Algarni, A. Alzahrani, A.A. Alsharef, R.F. Alhakeem, H.A.A. Jokhdar, A.M. Assiri); Centers for Disease Control and Prevention, Atlanta, Georgia, USA (C.M. Midgley, G.R. Abedi, X. Lu, A.M. Binder, A. Tamin, S. Lester, R.M. Dahl, S.K. Sakthivel, N.J. Thornburg, D.D. Erdman, J.T. Watson, S.I. Gerber); Princess Nourah Bint Abdulrahman University, Riyadh (W.M. Banjar); Prince Mohammed Bin Abdulaziz Hospital, Riyadh (A. Algwizani, F. Bafaqeeh, S.S. Ghazal)

DOI: https://doi.org/10.3201/eid2504.181595
Tnfection with Middle East respiratory syndrome (MERS) coronavirus (MERS-CoV) results in a wide range of clinical manifestations, from mild or asymptomatic illness to severe respiratory failure (1-8); infection has a reported mortality rate of $35 \%$ (9). Most MERS cases have been reported in older adults with underlying medical conditions $(4,7)$. Asymptomatic or mild infections are typically reported in younger, healthy adults, including healthcare personnel $(2,4)$. MERS-CoV transmission is commonly associated with exposure to symptomatic patients in healthcare $(1,2,10,11)$ or household (12) settings or with direct exposure to dromedary camels (13).

Infection prevention and control guidance for MERS$\mathrm{CoV}$ in humans is partially based on severe acute respiratory syndrome (SARS) coronavirus infection dynamics $(14,15)$; MERS-specific recommendations are incomplete. Investigations of virus shedding in MERS patients have demonstrated that MERS-CoV RNA can be detected in the respiratory tract for $>1$ month from illness onset $(16,17)$; lower respiratory tract (LRT) specimens have higher (18-23) and often more prolonged RNA levels $(17,18)$ than upper respiratory tract (URT) specimens; more severely ill patients typically have higher $(18,21)$ and more prolonged (18) RNA levels; and MERS-CoV RNA is detected in the blood $(17,22,24)$, serum $(18,19,24)$, plasma $(22,25,26)$, stool $(19,23,27)$, and urine $(17,19,23)$ of some patients. However, important knowledge gaps remain, particularly regarding shedding in association with clinical manifestations and host factors (4).

Serologic responses among MERS patients are incompletely understood; such data are critical for the development

\footnotetext{
${ }^{1}$ These first authors contributed equally to this article.
} 
of vaccines, antibody therapeutics, and diagnostics. Investigations of MERS survivors have demonstrated that antibody titers are higher and longer-lived in more severely ill patients than in mildly ill patients (28), some of whom do not develop a detectable response $(28,29)$. Antibodies are usually detected by day 21 after illness onset $(30,31)$ and can persist for $\geq 34$ months after infection (32). Data on case-patients who died, however, are limited $(19,25,29)$.

To address gaps in viral and antibody kinetics, we longitudinally assessed 33 hospitalized MERS-CoV-infected patients. Our aim was to characterize MERS-CoV infection dynamics and antibody responses in relation to outcome, clinical manifestations, underlying medical conditions, and preillness exposures.

\section{Methods}

\section{Patient Enrollment}

The study population was drawn from a MERS referral hospital in Riyadh, Saudi Arabia. All patients testing positive for MERS-CoV locally by real-time reverse transcription PCR (rRT-PCR) assay and admitted to this hospital during August 1, 2015-August 31, 2016, were eligible for participation. All enrolled patients provided informed written consent.

\section{Data Collection}

We reviewed epidemiologic interviews conducted at the time of case identification to include patient demographics, symptom history, and relevant exposures during the 2 weeks before onset. After patient death or discharge, we performed comprehensive medical chart reviews to collect medical history; symptoms before hospitalization; and daily information regarding symptoms during hospitalization, clinical course, treatments, medications, patient vital signs, diagnostic tests, and clinical outcome.

To assess MERS-CoV infection status, we retrospectively reviewed 3 data sources (as available) containing information on clinical diagnostic testing: 1) rRT-PCR request forms submitted to a regional testing facility; 2) hospital copies of corresponding results; and 3) if the hospital's clinical series was incomplete, rRT-PCR results from the Health Electronic Surveillance Network (33), a national platform for reporting notifiable diseases in Saudi Arabia. MERS-CoV clinical diagnostic testing had been performed on URT or LRT specimens typically collected every other day throughout hospitalization. Healthcare personnel collected LRT specimens from intubated patients and URT specimens otherwise. MERS-CoV results were positive, probable, or negative and, if available, cycle threshold $\left(\mathrm{C}_{\mathrm{t}}\right)$ values for MERS-CoV upstream of the envelope $\mathrm{E}$ (upE) or open reading frame (ORF) 1a (34); a probable finding indicated that only 1 of these 2 targets was detected.

\section{Laboratory Investigation}

In addition to retrospectively reviewing clinical MERS-CoV test results, we periodically collected specimens throughout hospitalization for molecular and serologic testing at the US Centers for Disease Control and Prevention (CDC). Specimens were collected from respiratory and nonrespiratory sites, frozen at $<-70^{\circ} \mathrm{C}$, and shipped on dry ice. Available specimens were URT (nasopharyngeal, oropharyngeal swab, or combined), LRT (sputum or tracheal aspirate), whole blood, serum, stool, and urine. Specimens were collected during days $1-42$ postenrollment and additionally at 1 year for serum.

\section{Molecular Assays}

Specimens were processed and screened by upE and N2 rRT-PCR. Specimens positive by only 1 RT-PCR were confirmed by N3 assay as previously described (35). MERS$\mathrm{CoV}$ isolation was performed as previously described (36). We attempted full genome sequencing, as previously described (36), on the earliest available respiratory specimen (or serum, if not available) for each patient.

\section{Serologic Assays}

Serum specimens with sufficient volume were tested using 4 CDC serologic assays: 1) microneutralization (MN) assay (37); 2) spike (S)-specific pseudoparticle neutralization assay (VSV-MERS-S); 3) S ELISA (Ig-specific) (38); and 4) nucleocapsid (N) ELISA (Ig-specific) $(37,38)$. Additional description is available in Appendix 1 (https://wwwnc.cdc.gov/EID/article/25/4/18-1595-App1.pdf).

\section{Data Analysis}

\section{Definitions}

We defined illness onset as the first day of reported symptoms consistent with MERS; for asymptomatic patients identified through routine contact investigations, we used the date of the first positive MERS-CoV test. We analyzed data relative to the date of illness onset (day 0). Patients were classified as having diabetes mellitus (DM) if there was a documented medical history of DM. Patients with multiple periods of hyperglycemia during hospitalization (random glucose readings $>200 \mathrm{mg} / \mathrm{dL}$ ), but with no documented medical history of DM, were considered as possible DM status.

Cardiac disease included congestive heart failure, coronary artery disease, or a history of myocardial infarction; reports of isolated hypertension were not included. Pulmonary disease included chronic obstructive pulmonary disease, asthma or reactive airway disease, or use of supplemental oxygen at home. Renal disease included reports of chronic kidney disease. Secondary exposure was defined as contact with MERS-CoV-infected persons in the 2 weeks 
before illness onset. Primary exposure was defined as either reported direct camel contact or no known contact with MERS-CoV-infected persons.

\section{IIIness Severity}

We retrospectively categorized patients into 3 groups on the basis of the need for supplemental oxygen, ventilation, and clinical outcome. Group 1 (G1) received room air throughout hospitalization; group 2 (G2) required ventilator support (mechanical or nonmechanical) and survived; and group 3 (G3) required ventilator support and died.

\section{MERS-CoV Detection Period}

To analyze duration of detectable MERS-CoV among survivors, we assessed the number of days from illness onset to negativity in clinical respiratory specimens tested at the regional testing facility, based on reports from the hospital or the Health Electronic Surveillance Network. We defined the day of MERS-CoV negativity as the first of $\geq 2$ consecutive negative tests before discharge. These variables were based on either URT or LRT specimens. Because mildly ill patients did not provide LRT specimens, we only assessed detection in URT specimens when comparing severity groups.

\section{Prolonged MERS-CoV Detection}

To assess prolonged MERS-CoV detection, we expressed time to negativity as a binary variable: patients with time to negativity $\leq 11$ versus $>11$ days. We chose this cutoff to reflect the median time to negativity among survivors. Given the low numbers of patients in our cohort, we also assessed 2 additional cut-offs for prolonged shedding to strengthen statistically significant findings: $\leq 14$ versus $>14$ days and $\leq 21$ versus $>21$ days.

\section{Viral Load}

To approximate viral load in clinical results, we assessed MERS-CoV upE rRT-PCR $\mathrm{C}_{\mathrm{t}}$ values determined at the regional testing facility. We used $\mathrm{C}_{t}$ values from LRT specimens to assess mechanically ventilated patients. We were able to identify the minimum $\mathrm{C}_{\mathrm{t}}$ value (or peak RNA level)

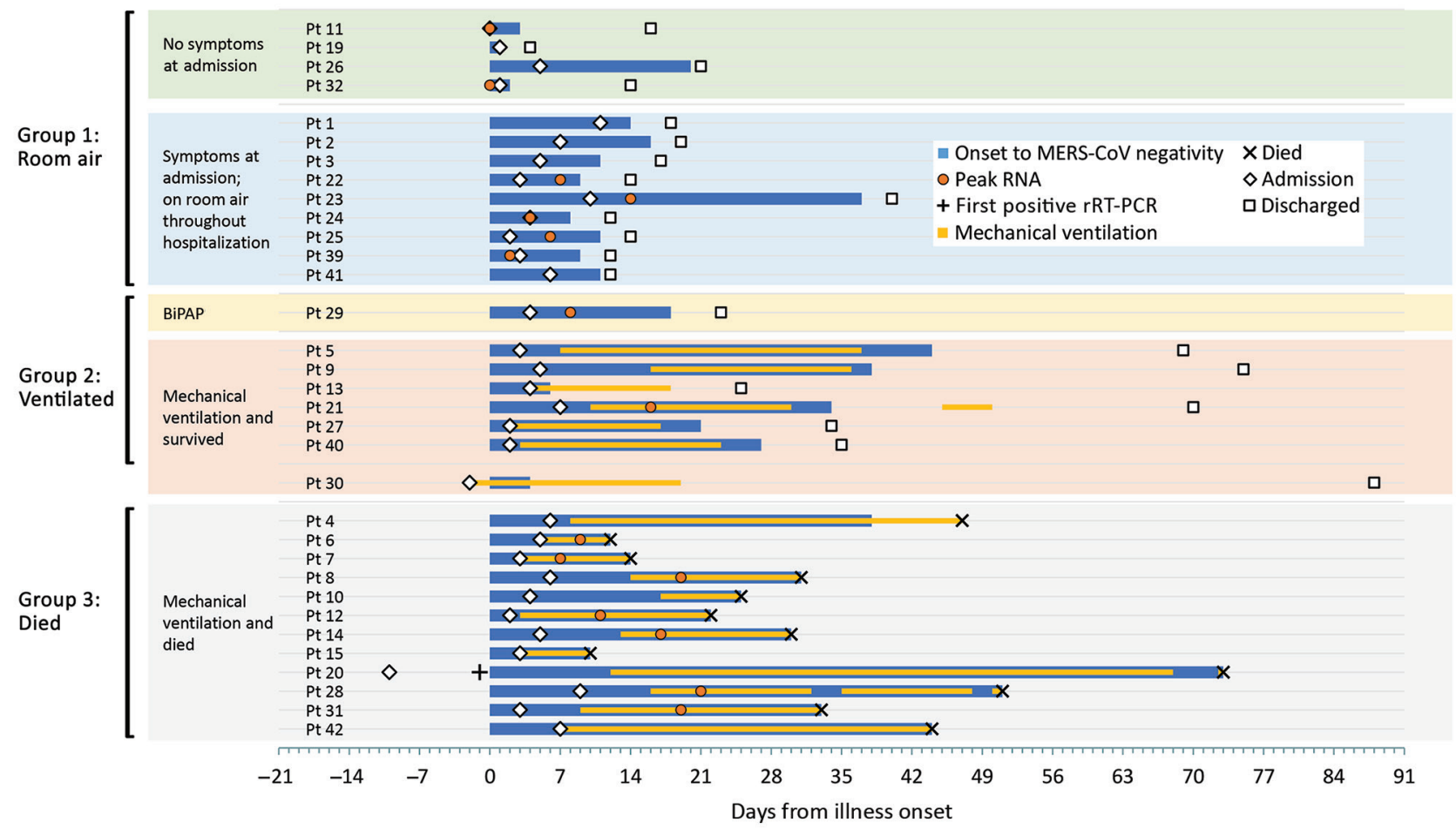

Figure 1. Timeline of clinical course and MERS-CoV detection, by patient, Saudi Arabia, August 1, 2015-August 31, 2016. Findings are presented by time since illness onset (day 0). Patients are grouped by illness severity and outcome. For each patient, day of admission, discharge or death, period of mechanical ventilation (if applicable), and MERS-CoV detection are depicted. For a subset of patients with sufficient data, the peak RNA level (or the minimum upstream of the envelope cycle threshold value) is depicted. Peak RNA was based on upper respiratory tract specimen results among group 1 patients and $\mathrm{Pt} 29$, and lower respiratory tract specimen results in group 2 and group 3 patients. The date of death is shown for group 3 patients. Pt 11 and Pt 32 did not report any symptoms throughout their hospitalization. Pt 30 was hospitalized and mechanically ventilated before MERS onset because of a road traffic accident; this patient was excluded from severity and clinical course analyses. Pt 23 has been described previously (36). The first positive MERS-CoV rRTPCR for Pt 20 was collected 1 day before symptom onset. BiPAP, bilevel positive airway pressure; CoV, coronavirus; MERS, Middle East respiratory syndrome; Pt, patient; rRT-PCR, real-time reverse transcription PCR. 
Table 2. Demographic and exposure characteristics of survivors with prolonged MERS-CoV detection, Saudi Arabia, August 1, 2015August 31, 2016*

\begin{tabular}{|c|c|c|c|c|}
\hline \multirow[b]{2}{*}{ Characteristic } & \multirow[b]{2}{*}{ Total, $\mathrm{N}=19$} & \multicolumn{2}{|c|}{ Days to negativity } & \multirow[b]{2}{*}{$\mathrm{p}$ value } \\
\hline & & $\leq 11 \mathrm{~d}, \mathrm{n}=11$ & $>11 \mathrm{~d}, \mathrm{n}=8$ & \\
\hline \multicolumn{5}{|l|}{ Demographics } \\
\hline \multicolumn{5}{|l|}{ Sex } \\
\hline M & $13 / 19(68)$ & 6/11 (55) & $7 / 8(88)$ & 0.177 \\
\hline $\mathrm{F}$ & $6 / 19(32)$ & $5 / 11(45)$ & $1 / 8(12)$ & \\
\hline \multicolumn{5}{|l|}{ Nationality } \\
\hline Saudi & $10 / 19(53)$ & $5 / 11(45)$ & $5 / 8(63)$ & 0.650 \\
\hline Non-Saudi & $9 / 19(47)$ & $6 / 11(55)$ & $3 / 8(37)$ & \\
\hline \multicolumn{5}{|l|}{ Age group, $y$} \\
\hline $25-44$ & $14 / 19(74)$ & $9 / 11(82)$ & $5 / 8(63)$ & 0.262 \\
\hline $45-64$ & $4 / 19(21)$ & $1 / 11(9)$ & $3 / 8(38)$ & \\
\hline$\geq 65$ & $1 / 19(5)$ & $1 / 11(9)$ & $0 / 8$ & \\
\hline Médian age, y (range) & $36(26-73)$ & $30(26-73)$ & $40(27-62)$ & 0.083 \\
\hline \multicolumn{5}{|l|}{ Underlying conditions } \\
\hline None reported & $10 / 19(53)$ & $8 / 11(73)$ & $2 / 8(25)$ & 0.070 \\
\hline Any reported underlying condition & $9 / 19(47)$ & $3 / 11(27)$ & $6 / 8(75)$ & \\
\hline $\mathrm{DM} \ddagger$ & $7 / 18$ (39) & $2 / 11(20)$ & $5 / 7(71)$ & 0.049 \\
\hline DM and possible DM§ & $8 / 19(42)$ & $2 / 11(20)$ & $6 / 8(75)$ & 0.024 \\
\hline Hypertension & $3 / 19(16)$ & $1 / 11(9)$ & $2 / 8(25)$ & 0.546 \\
\hline Cardiac diseaseף & $1 / 19(5)$ & $1 / 11(9)$ & $0 / 8$ & 1.000 \\
\hline Pulmonary disease\# & $1 / 19(5)$ & $1 / 11(9)$ & $0 / 8$ & 1.000 \\
\hline On oxygen at home ${ }^{* *}$ & $1 / 19(5)$ & $1 / 11(9)$ & $0 / 8$ & 1.000 \\
\hline \multicolumn{5}{|l|}{ Possible preillness exposure } \\
\hline Secondary, $\dagger \dagger$ healthcare personnel & $5 / 19(26)$ & $4 / 11(36)$ & $1 / 8(13)$ & NA \\
\hline Secondary, household contact & $5 / 19(26)$ & $3 / 11(27)$ & $2 / 8(25)$ & NA \\
\hline Secondary, hospital visitor & $3 / 19(16)$ & $0 / 11$ & $3 / 8(38)$ & NA \\
\hline Secondary, hospital inpatient & $0 / 19$ & $0 / 11$ & $0 / 8$ & NA \\
\hline Any secondary exposure & $13 / 19(68)$ & $7 / 11(64)$ & $6 / 8(75)$ & 0.796 \\
\hline Direct camel contact & $0 / 19$ & $0 / 11$ & $0 / 8$ & \\
\hline Multiple possible exposures & $2 / 19(11)$ & $1 / 11(9)$ & $1 / 8(13)$ & \\
\hline No recognized risks执 & $4 / 19(21)$ & $3 / 11$ (27) & $1 / 8(13)$ & \\
\hline \multicolumn{5}{|l|}{ Primary vs. secondary exposure§§ } \\
\hline Primaryণा & $4 / 17(24)$ & $3 / 10(30)$ & $1 / 7(14)$ & 0.603 \\
\hline Secondary & $13 / 17(78)$ & $7 / 10(70)$ & $6 / 7(86)$ & \\
\hline \multicolumn{5}{|c|}{ 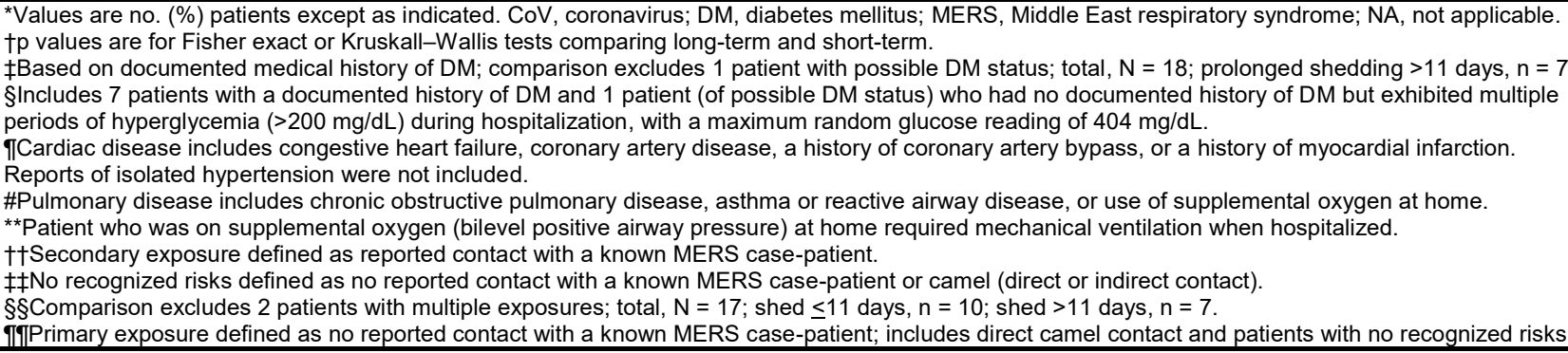 } \\
\hline
\end{tabular}

in a subset of patients. For specimens submitted to CDC, we estimated viral load on the basis of the upE $\mathrm{C}_{t}$ value (or N2 $\mathrm{C}_{\mathrm{t}}$ value if upE testing was negative and $\mathrm{N} 3$ was positive).

\section{Antibody Responses}

We compared the proportion of serum specimens with detectable antibody responses between survivors and patients who died. We assessed specimens collected $<14,<21$, and $<28$ days after illness onset; during 28-56 days after onset; and then at 1 year.

\section{Statistical Analyses}

We summarized patient characteristics by illness severity and, among survivors, by time to MERS-CoV negativity.
We used Fisher exact, Kruskall-Wallis, or log rank tests to compare groups and exact logistic regression for multivariable analysis. We compared antibody titers with estimated viral load in different specimen types by using the Spearman test for correlation. All data were analyzed using Microsoft Excel 2016 (https://products.office.com) and SAS version 9.4 (https://www.sas.com).

\section{Results}

\section{Cohort Description}

During August 1, 2015-August 31, 2016, a total of 33 MERS-CoV-infected patients were enrolled. Among these, 4 were classified as asymptomatic on admission, and 
Table 3. Clinical features of survivors with prolonged MERS-CoV detection, Saudi Arabia, August 1, 2015-August 31, 2016*

\begin{tabular}{|c|c|c|c|c|}
\hline \multirow[b]{2}{*}{ Clinical feature } & \multirow[b]{2}{*}{ Total, $\mathrm{N}=19$} & \multicolumn{2}{|c|}{ Days to negativity } & \multirow[b]{2}{*}{$\mathrm{p}$ value } \\
\hline & & $\leq 11 \mathrm{~d}, \mathrm{n}=11$ & $>11 \mathrm{~d}, \mathrm{n}=8$ & \\
\hline \multicolumn{5}{|l|}{ Symptoms before admission $\ddagger$} \\
\hline No symptoms & $4 / 18(21)$ & $3 / 10(30)$ & $1 / 8(13)$ & 0.603 \\
\hline Fever & $13 / 18(72)$ & $7 / 10(70)$ & $6 / 8(75)$ & 1.000 \\
\hline Cough & $11 / 18(61)$ & $5 / 10(50)$ & $6 / 8(75)$ & 0.367 \\
\hline Dyspnea & $6 / 18(33)$ & $2 / 10(20)$ & $4 / 8(50)$ & 0.321 \\
\hline Vomiting & $5 / 18(28)$ & $2 / 10(20)$ & $3 / 8(38)$ & 0.608 \\
\hline Diarrhea & $3 / 18$ (17) & $0 / 10$ & $3 / 8(38)$ & 0.069 \\
\hline \multicolumn{5}{|l|}{ Clinical course } \\
\hline Room air & $13 / 18(72)$ & 9/10 (90) & $4 / 8(50)$ & 0.118 \\
\hline Ventilator support§ & $5 / 18(28)$ & $1 / 10(10)$ & $4 / 8(50)$ & \\
\hline Abnormal chest radiograph & $9 / 18(50)$ & $4 / 10(40)$ & $5 / 8(63)$ & 0.637 \\
\hline \multicolumn{5}{|l|}{ Medications } \\
\hline Ribavirin plus peg-IFN $\alpha$ & $2 / 19(11)$ & $0 / 11$ & $2 / 8(25)$ & 0.164 \\
\hline Oseltamivir & $12 / 19(63)$ & 6/11 (55) & $6 / 8(75)$ & 0.633 \\
\hline Antibiotics & $15 / 19(79)$ & $8 / 11(73)$ & $7 / 8$ (88) & 0.603 \\
\hline Parenteral steroids & $3 / 19(16)$ & $0 / 11$ & $3 / 8(38)$ & 0.058 \\
\hline Group 2 only\# & $3 / 5(60)$ & $0 / 1$ & $3 / 4(75)$ & 0.400 \\
\hline Inhaled steroids & $2 / 19$ (11) & $0 / 11$ & $2 / 8(25)$ & 0.164 \\
\hline Group 2 only\# & $2 / 5(40)^{\prime}$ & $0 / 1$ & $2 / 4(50)$ & 1.000 \\
\hline Bronchodilators & $5 / 19(26)$ & 2/11 (18) & $3 / 8(38)$ & 0.603 \\
\hline Antipyretics & 9/19 (47) & 6/11 (55) & $3 / 8(38)$ & 0.650 \\
\hline
\end{tabular}

*Values are no. (\%) patients except as indicated. Group 2, ventilated but survived; MERS-CoV, Middle East respiratory syndrome coronavirus.

tp values are for Fisher exact or Kruskall-Wallis tests comparing long-term and short-term.

†Excludes patient no. 30, who was admitted and intubated before onset because of injuries sustained in a road traffic accident $(\mathrm{N}=18)$.

§Includes mechanical or nonmechanical (i.e., bilevel positive airway pressure) ventilation.

TMedication given during MERS-CoV detection period (on the basis of diagnostic testing in respiratory specimens).

\#Assessing steroid use among G2 patients only.

9 reported symptoms but remained on room air during hospitalization (Figure 1; Appendix 1 Figure 1; Appendix 2 Table 1, https://wwwnc.cdc.gov/EID/article/25/4/18-1595App1.xlsx); 10 of these 13 patients were identified through contact tracing (5 were healthcare personnel) and were hospitalized to ensure isolation. Twenty patients required ventilator support (1 bilevel positive airway pressure [BiPAP] and 19 mechanical ventilation), 12 of whom died. We grouped 13 patients into G1, 7 into G2, and 12 into G3; 1 patient (patient [Pt] 30) was initially hospitalized and intubated after a road traffic accident, before MERS onset, and was excluded from analyses regarding severity and clinical course resulting from MERS-CoV infection.

Patient ages ranged from 26 to 78 years, and $63 \%$ were male (Appendix 2 Table 1). Twenty-three (70\%) patients had $>1$ underlying medical condition, 19 of whom had documented DM; an additional 3 patients were considered of possible DM status because they exhibited multiple periods of hyperglycemia (random glucose readings $>395 \mathrm{mg} / \mathrm{dL}$ ) but had no documented history of DM. Death was associated with older age $(\mathrm{p}<0.001)$, DM $(\mathrm{p}=0.001)$, hypertension $(p<0.001)$, cardiac disease $(p=0.001)$, or renal disease $(p=$ 0.001 ) (Table 1). Among survivors, ventilator support was associated with DM $(p=0.047)$, older age $(p=0.047)$, or preillness primary exposure $(\mathrm{p}=0.046)$ (Table 1$)$. Among the 12 patients with a primary exposure, 8 had DM (Appendix 2 Table 1).

Clinical course and time to MERS-CoV negativity (in clinical respiratory specimens) is depicted according to date of illness onset (Figure 1; Appendix 2 Table 2). Time to admission (median 4 days) did not differ between groups. Time to MERS-CoV negativity among survivors ranged from day 1 to day 44 after illness onset and was typically longer among G2 than G1 patients. Twelve of 13 patients in G1 were discharged by day 21 after onset; the mildly ill patient who was in the hospital until day 40 after onset ( $\mathrm{Pt} 23$ ) has been described previously (36). Duration of hospitalization for G2 patients was 19-70 days, and duration of intubation was 14-31 days. G3 patients died 10-73 days after onset.

\section{Daily Symptoms}

Common symptoms before admission were fever (78\%), cough (72\%), and dyspnea (59\%) (Table 1). Dyspnea before admission was associated with a more severe outcome $(p<0.001)$. Among the 4 patients who reported no symptoms on admission, 2 were mildly symptomatic during hospitalization (Appendix 2 Table 3).

Among G1 patients, fever and cough were commonly reported, and the proportion of patients with either symptom appeared to align with the proportion who concurrently had detectable MERS-CoV in clinical respiratory specimens (Figure 2, panel A). Cough persisted in 5 G1 patients for $\leq 4$ days after MERS-CoV negativity (Figure 2, panel B). Chest radiographs of 4 G1 patients were described as abnormal, typically with unilateral findings (Appendix 2 Table 4). Oxygen saturation remained $>92 \%$ in G1 patients. Among G2 patients, 
the proportion of patients mechanically ventilated appeared to align with the proportion who had detectable MERS-CoV in the LRT (Figure 2, panel C); only $1 \mathrm{G} 2$ patient ( $\mathrm{Pt}$ 13, who had underlying pulmonary disease) was MERS-CoV-positive for a short period but required extended mechanical ventilation. Among the $12 \mathrm{G} 3$ patients, 11 were MERS-CoV RNA-positive until death (Figure 2, panel D).

\section{MERS-CoV RNA in Respiratory Specimens}

MERS-CoV upE $\mathrm{C}_{\mathrm{t}}$ values from clinical diagnostic reports are depicted in Figure 3. MERS-CoV RNA levels in the URT of most G1 patients peaked in the first week after onset (Figure 3, panel D). Among patients who died, RNA levels peaked in the LRT during weeks 2 and 3 (Figure 3, panel E), after which RNA levels typically began to decrease (Figure 3, panel C); 4 patients died with negative or probable rRT-PCR results.
A

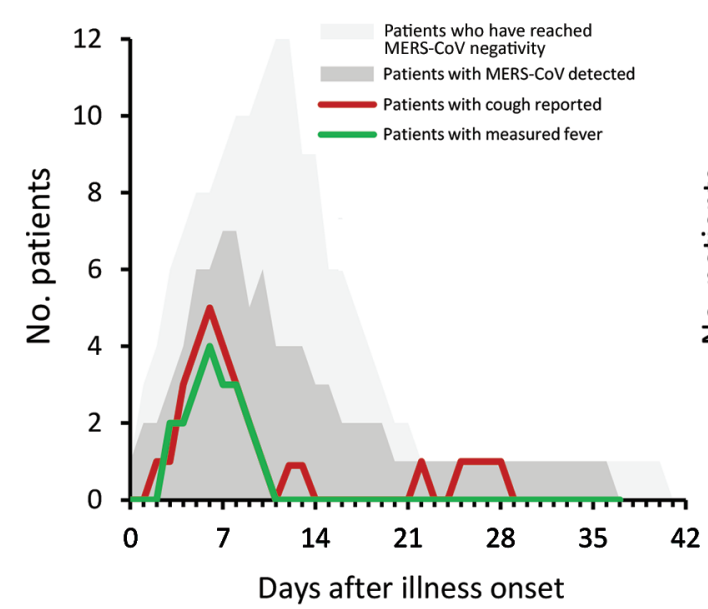

Days after illness onset
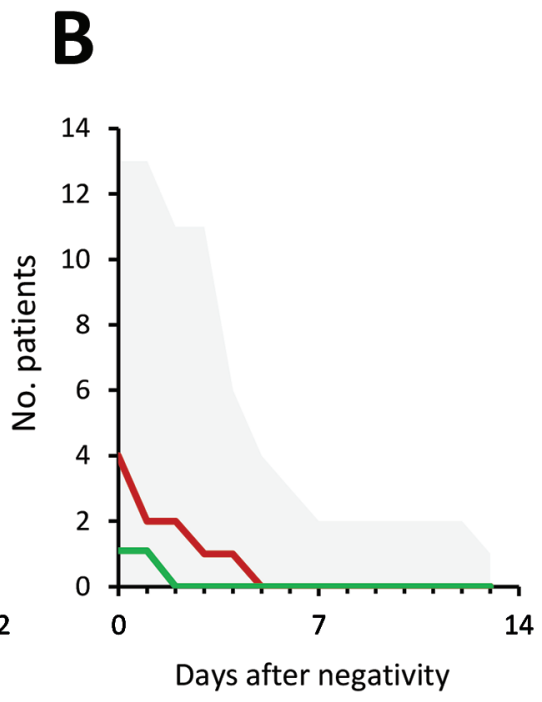

C

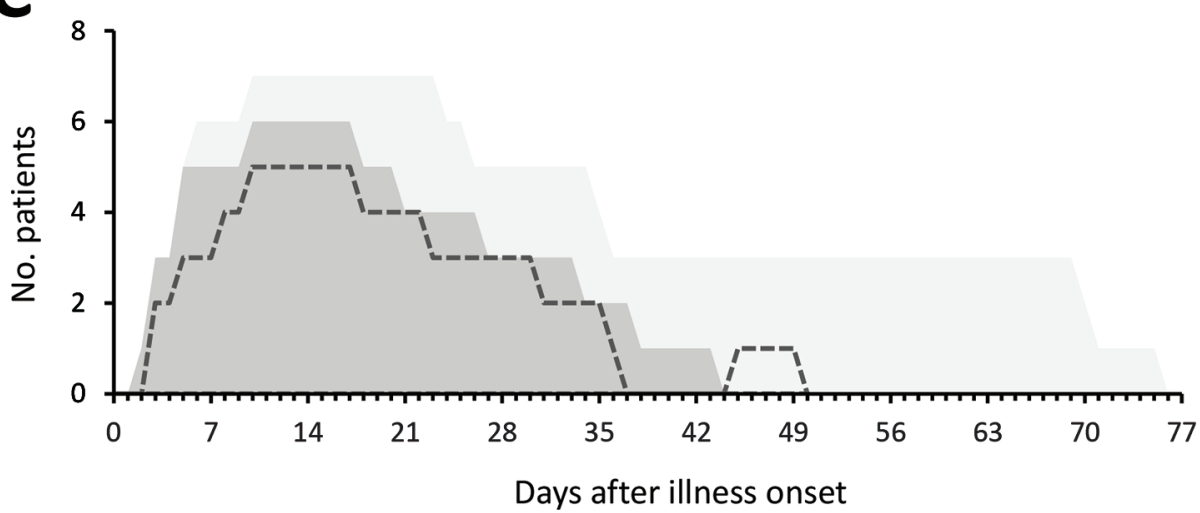

D

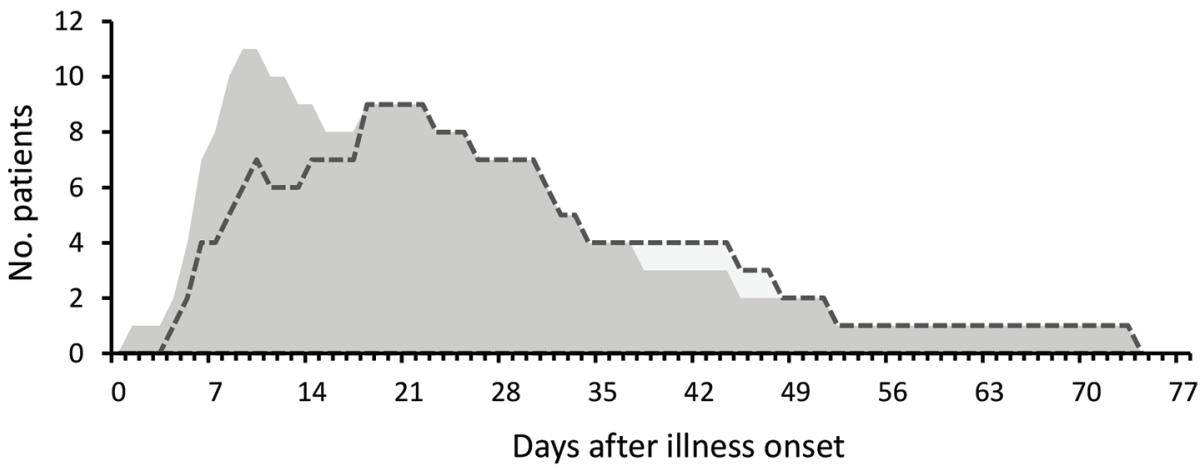

Figure 2. Symptom progression and MERS-CoV detection during hospitalization at a MERS referral hospital, Saudi Arabia, August 1, 2015-August 31, 2016. Each panel depicts the number of patients hospitalized on a given day for each category shown; MERS-CoV detection is based on the clinical diagnostic reports in the upper or lower respiratory tract. A, B) Number of group 1 patients with fever (measured oral temperature $>38.0^{\circ} \mathrm{C}$ or measured axillary temperature $>37.5^{\circ} \mathrm{C}$ ) and reported cough during $(A)$ and after $(B)$ the

MERS-CoV detection period. C, D) Number of patients intubated (dashed lines) and the number of patients who were positive for MERS-CoV on a given day for group 2 (C) and group 3 (D). MERS, Middle East respiratory syndrome; MERS-CoV, Middle East respiratory syndrome coronavirus. Group 1, on room air; group 2, ventilated but survived; group 3, died. 
We next assessed characteristics of survivors with prolonged MERS-CoV detection periods (on the basis of clinical diagnostic reports of URT specimens) (Tables 2, 3; Appendix 2 Tables 5,6 ). Patients who reached negativity $>11$ days after onset were more likely to have DM than patients who cleared the virus earlier $(p=0.049$; when adjusting for severity group, $\mathrm{p}=0.061)($ Tables 2,3$)$. This association was also observed in patients who reached negativity $>14$ days after onset $(p=0.013)$ and when adjusting for severity group $(p=0.030)$ (Appendix
2 Table 5). Evidence for this association was stronger when patients with DM and possible DM were combined (Tables 2, 3; Appendix 2 Table 5). No other underlying medical conditions were associated with prolonged detection. Survivors with prolonged detection ( $>14$ or $>21$ days) were also more likely to require ventilator support (Appendix 2 Table 5), but this was not significant when adjusting for DM.

Based on respiratory specimens submitted to CDC (Appendix 1 Figures 2, 3), full-genome sequences from 13
Figure 3. MERS-CoV RNA detection in the respiratory tract, based on clinical diagnostic reports, among MERS-CoV patients, Saudi Arabia, August 1, 2015-August 31, 2016.

A-C) UpE real-time reverse transcription PCR $C_{t}$ values of group $1(A), 2(B)$, and $3(C)$ patients, by days since illness onset (day 0). Panel A depicts URT specimens, and panels $B$ and $C$ depict LRT specimens collected during MV; Pt 29 (a G2 patient who received BiPAP ventilation) is depicted in panel A because only URT specimens were collected for this patient. The dashed line represents the limit of detection, above which specimens were considered MERS-CoV-negative or not detected. Probable results, meaning that only 1 of 2 realtime reverse transcription PCR assays were positive, are depicted on the dashed line for graphing purposes. Patients with limited $C_{t}$ values or unknown specimen types are not depicted. Patients 11 and 32 did not report any symptoms throughout their illness. Pt 30 is depicted alongside $\mathrm{G} 2$ patients. Pt 23 reached negativity 37 days after illness onset, as described previously (36). *Indicates patients with a documented history of diabetes mellitus. D, E) Minimum $C_{t}$ values reported, which was determined for a subset of patients with sufficient data. Panel D depicts URT specimen results among group 1 patients and Pt 29; panel E depicts LRT specimen results in group 2 and 3 patients, collected from the LRT during MV. Group 1, on room air; group 2, ventilated but survived; group 3, died. BiPAP, bilevel positive airway pressure; $\mathrm{C}_{t}$, cycle threshold; CoV, coronavirus; LRT, lower respiratory tract; MERS, Middle East respiratory syndrome; min, minimum; MV, mechanical ventilation; Pt, patient; URT, upper respiratory tract; upE, upstream of the envelope.

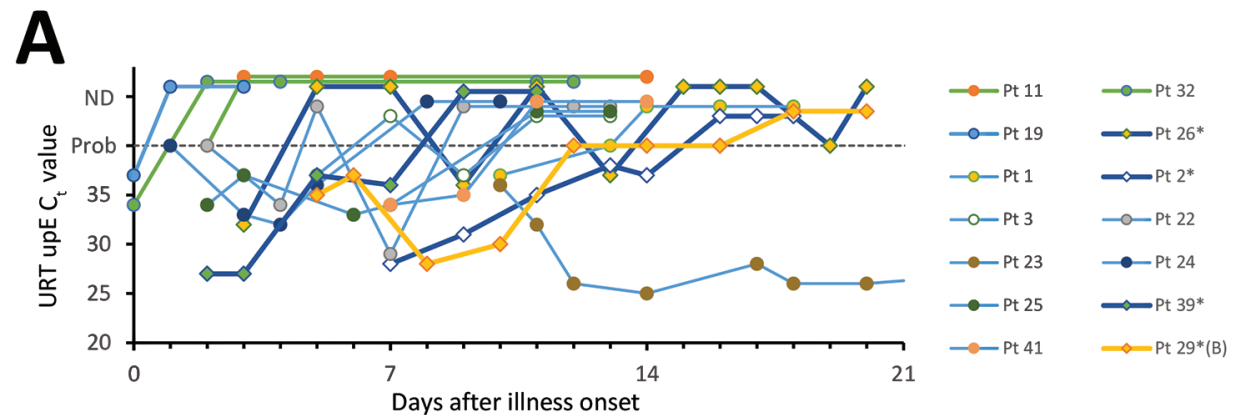

B
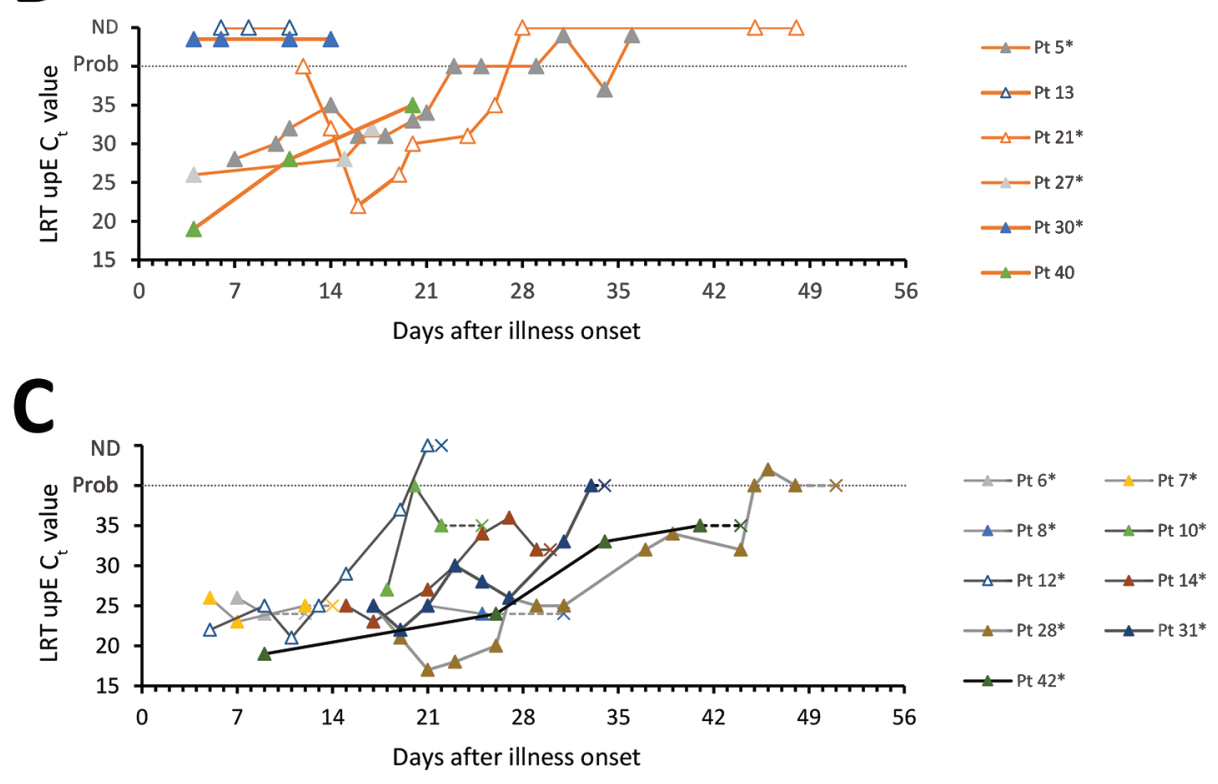

D
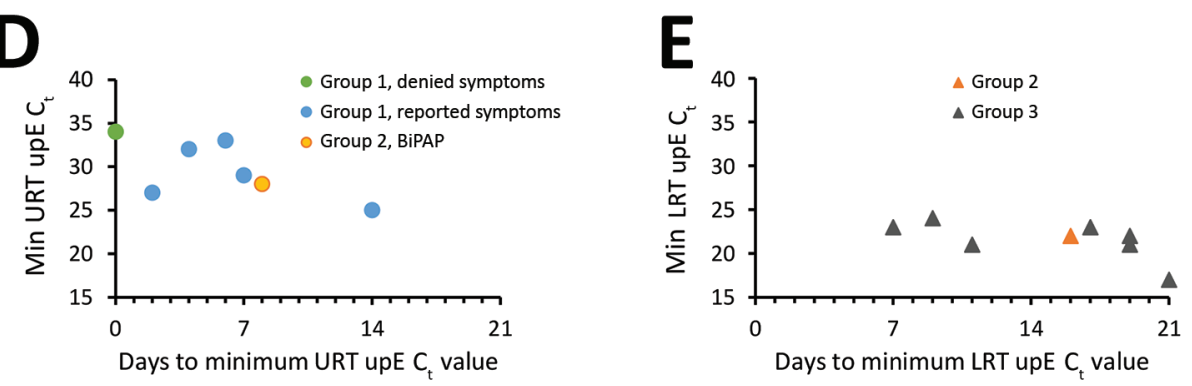
patients belonged to the NRC-2015 (39) clade (or lineage 5 [40]) (GenBank accession nos. MG520075 and MG757593MG757605). Viable MERS-CoV was isolated from 3 of 37 URT specimens; 2 specimens were from a mildly ill patient (Pt 23) collected on days 13 and 15 after onset (described previously [36]), and 1 specimen was collected on day 13 from a patient who subsequently died (Pt 8).

\section{MERS-CoV RNA in Nonrespiratory Specimens}

CDC received 252 nonrespiratory specimens for MERSCoV testing, collected from 31 patients $<3$ months after onset; 7 patients (21 specimens, all MERS-CoV-negative) were excluded because specimens were only collected after the virus had been cleared from the respiratory tract. Fourteen of 24 patients had MERS-CoV RNA detected in whole blood, 9/20 in serum, 5/10 in stool, and 3/16 in urine (Figure 4; Appendix 2 Table 2). In G1, MERS-CoV RNA was detected in the whole blood or serum of $4 / 8$ patients $(\leq 2.3 \times$ $10^{3}$ copies $/ \mathrm{mL}$ ) for $\leq 13$ days and in the stool of $3 / 5$ patients $\left(\leq 7.5 \times 10^{3}\right.$ copies $\left./ \mathrm{mL}\right)$ for $\leq 15$ days; only 1 patient with RNA-positive stool had concurrent gastrointestinal symptoms. Specimens were limited in G2, but MERS-CoV RNA
Group 1: Room air
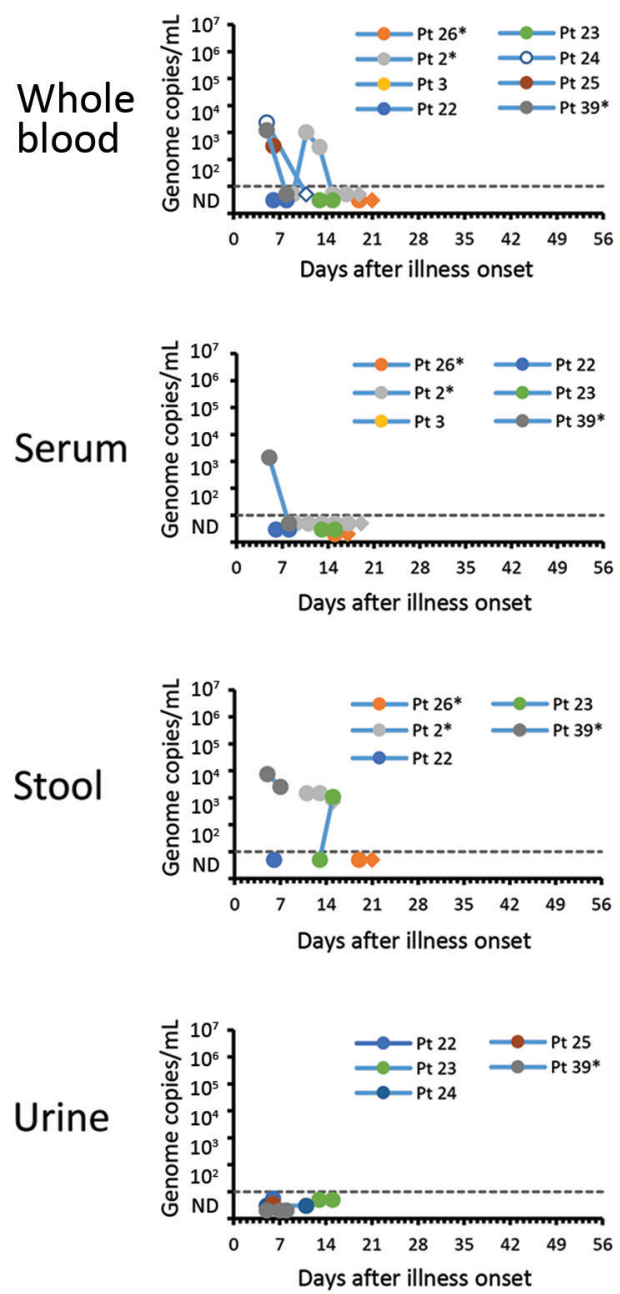

Group 2: Ventilated
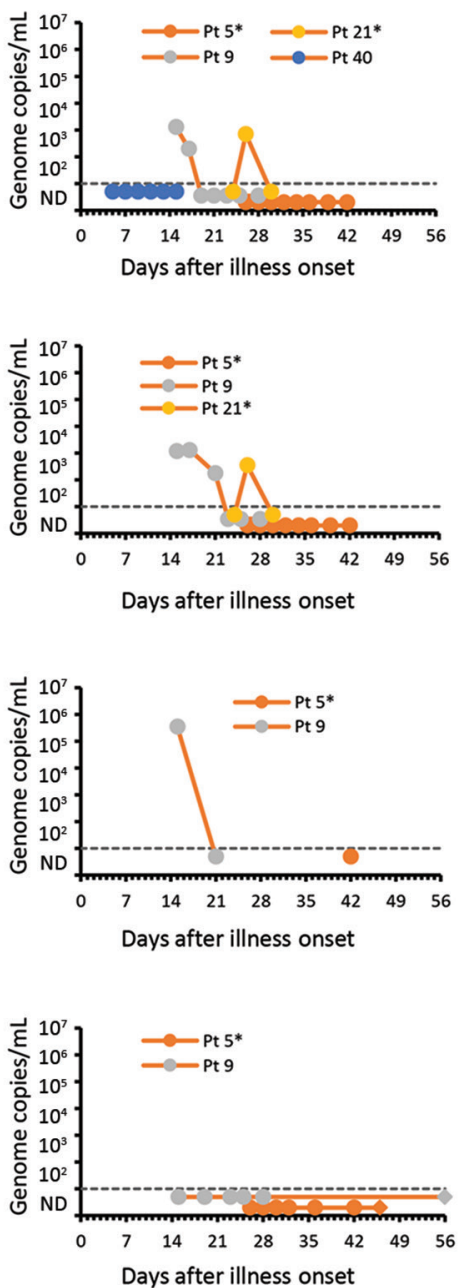

Group 3: Died
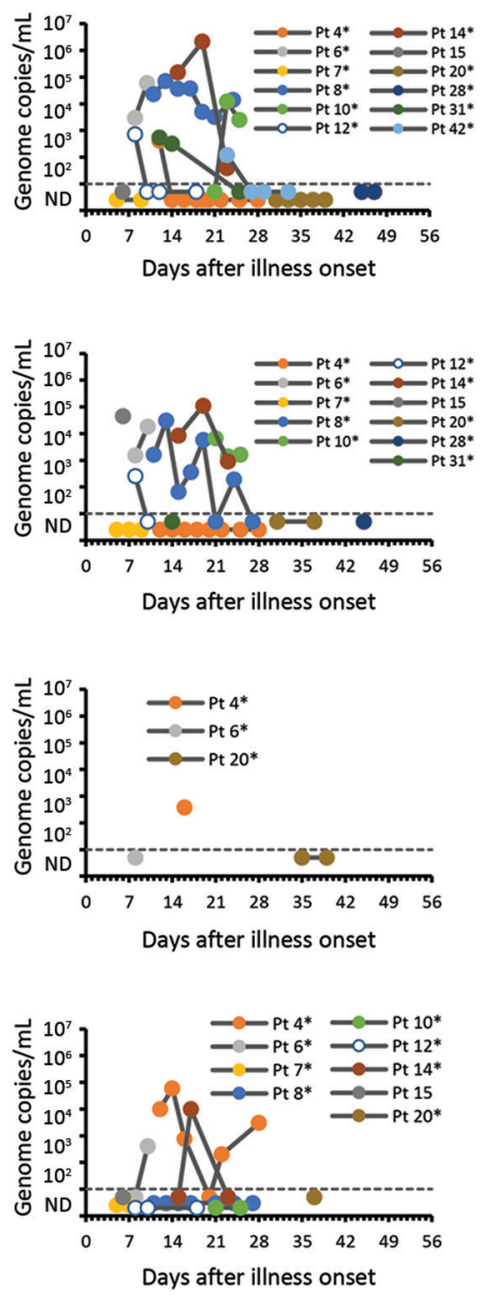

Figure 4. Estimated viral loads in non-respiratory tract specimens collected from hospitalized MERS-CoV patients, Saudi Arabia, August 1, 2015-August 31, 2016, and submitted to the US Centers for Disease Control and Prevention. Specimen types are shown by severity group. Estimated viral loads are based on upstream of the envelope (upE) real-time reverse transcription PCR cycle threshold values, or N2 cycle threshold values if the upe real-time reverse transcription PCR was negative. The dashed line represents the limit of detection, below which specimens were considered MERS-CoV-negative or not detected. Round data points represent specimens collected during the MERS-CoV detection period (defined by clinical results from respiratory specimens). Diamond data points represent specimens collected after the MERS-CoV detection period (defined by clinical results from respiratory specimens); no specimens were positive for MERS-CoV after the detection period. *Patients with a documented history of diabetes mellitus. MERS-CoV, Middle East respiratory syndrome coronavirus; Pt, patient. 
was detected in the blood of $2 / 4$ patients $\left(\leq 1.3 \times 10^{3}\right.$ copies/ $\mathrm{mL})$ and the stool of $1 / 2\left(3.5 \times 10^{5}\right.$ copies $\left./ \mathrm{mL}\right)$. In G3, high viral loads were detected in the whole blood or serum of 9 patients, reaching as high as $2.1 \times 10^{6}$ copies $/ \mathrm{mL}$. All 3 patients with MERS-CoV RNA detected in urine died $(<6.0 \times$ $10^{4}$ copies $\left./ \mathrm{mL}\right) ; 1$ patient had chronic kidney disease. We attempted but were unable to isolate live MERS-CoV from 5 stool specimens and 3 urine specimens with elevated MERS-CoV RNA levels.
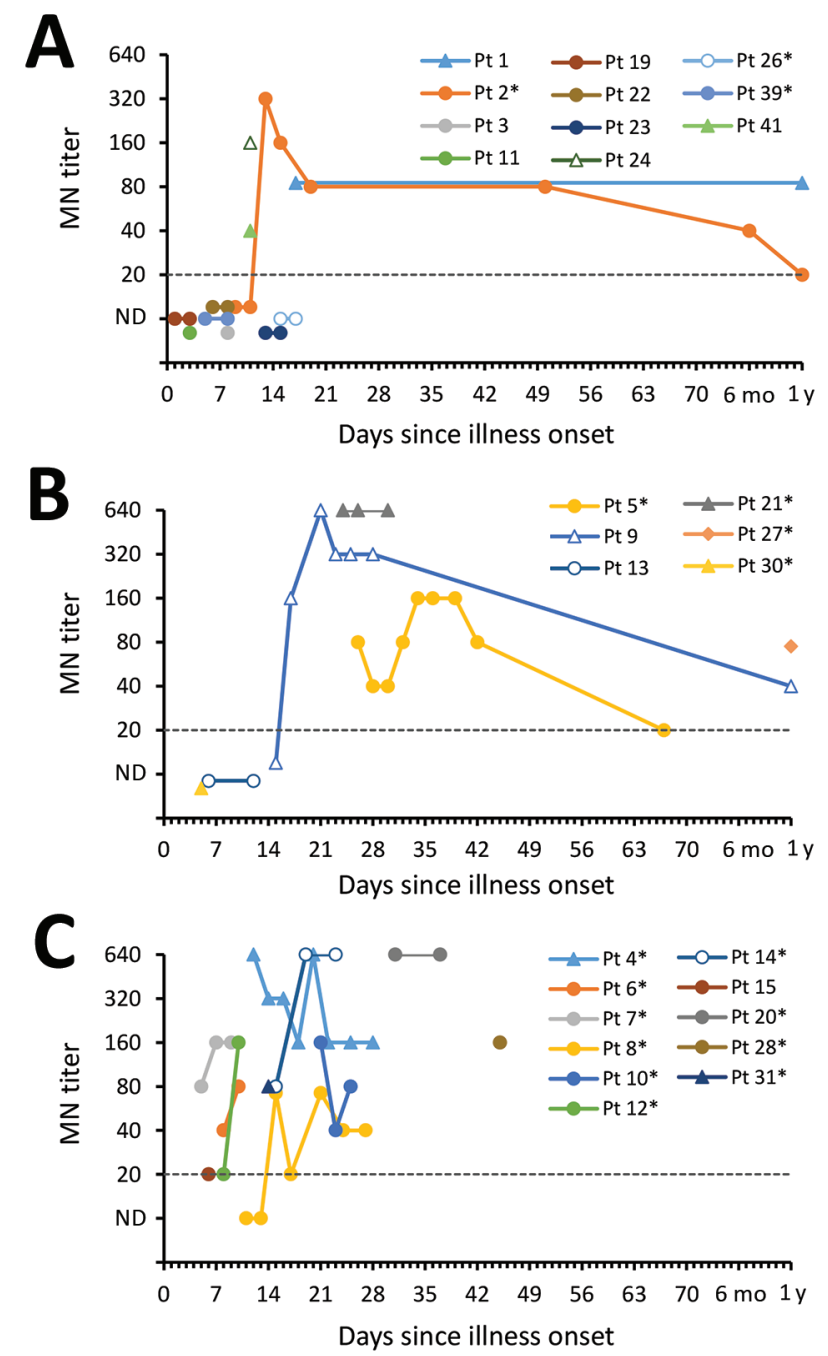

Figure 5. MN antibody titers of serum collected from MERS-CoV patients, by patient, severity group, and days since illness onset (day 0), Saudi Arabia, August 1, 2015-August 31, 2016. A) Group 1 patients; B) group 2 patients; C) group 3 patients. The dashed line represents the limit of detection, below which specimens were considered not to have detectable antibodies. Pt 11 did not report any symptoms throughout their illness. Pt 30 was hospitalized and mechanically ventilated before MERS onset because of a road traffic accident. *Patients with documented history of diabetes mellitus. MERS-CoV, Middle East respiratory syndrome coronavirus; MN, microneutralization assay; ND, antibodies not detected; Pt, patient.

\section{Serum Antibody Responses}

CDC tested 74 serum specimens collected $\leq 56$ days after onset; 41 specimens were from 16 survivors, and 33 specimens were from 11 case-patients who died. Time between onset and collection did not differ between patient groups (survived, median 15 days, range 1-50 days; died, median 17 days, range 5-45 days). Four specimens from 4 survivors were collected $\approx 1$ year after illness onset. Time courses of antibody responses are shown by patient in Figure 5 and Appendix 1 Figures 4-6.

Among case-patients who died, 5/6 had detectable neutralizing responses during the first 2 weeks of illness; by week 3 , all of these case-patients with available specimens had detectable antibodies by MN (Table 4). Notably, 1 of these case-patients exhibited a 9-day delay in the development of a detectable response by VSV-MERS-S pseudoparticle assay compared with MN (Appendix 1 Figure 7); the detectable S-specific response by ELISA was also delayed for this patient. Overall, the 2 neutralizing assays were better correlated in specimens from survivors than from patients who died (Appendix 1 Figure 8).

Survivors and case-patients who died had responses by $\mathrm{N}$ - and S-ELISA (Table 4), although detectable Nspecific responses preceded S-specific responses in 3 patients. By 1 year, $\mathrm{N}$-specific responses had waned in 2 of the 4 patients tested.

\section{Co-detection of Antibodies and Viral RNA}

We next compared neutralizing antibody titers to estimated viral load in the same serum specimen and to estimated viral load in respiratory specimens collected on the same day (Figure 6; Appendix 1 Figure 9). Among specimens with detectable antibodies by MN (Figure 6), viral RNA was often co-detected in serum, URT, and LRT specimens, even beyond 21 days after onset, when antibody titers were typically higher. Co-detection in serum $(p=0.032)$ and URT ( $p$ $=0.003$ ) specimens was observed more frequently among patients who died than among those who survived.

\section{Discussion}

We characterized MERS-CoV infection dynamics by patient demographics, underlying medical conditions, exposure route, and symptom progression and antibody responses by clinical outcome. Our findings demonstrate a possible association between DM and prolonged MERS-CoV RNA detection in survivors, when adjusting for severity. The prevalence of DM is high in Saudi Arabia; estimated national prevalence ranges from $14.4 \%(41)$ to $18.6 \%$ (42). $\mathrm{DM}$ is frequently reported among MERS case-patients $(7,43)$, is a risk factor for illness among those with primary exposures (13), and has been associated with increased severity $(44)$ and mortality $(26,44)$, as was observed in our study. DM was less frequently reported in MERS patients 
Table 4. Specimens and MERS-CoV-infected patients with detectable Abs, by time since illness onset and outcome, Saudi Arabia, August 1, 2015-August 31, 2016*

\begin{tabular}{|c|c|c|c|c|c|c|c|c|c|}
\hline \multirow[b]{2}{*}{ Outcome } & \multirow{2}{*}{$\begin{array}{c}\text { Days since } \\
\text { onset }\end{array}$} & \multicolumn{4}{|c|}{ No. specimens with Abs detected/no. tested } & \multicolumn{4}{|c|}{ No. patients $\dagger$ with Abs detected/no. tested } \\
\hline & & $\mathrm{MN}$ & VSV-MERS-S & S ELISA & N ELISA & $\mathrm{MN}$ & VSV-MERS-S & S ELISA & N ELISA \\
\hline \multirow[t]{5}{*}{ Survived } & $<14$ & $3 / 17$ & $4 / 16$ & $5 / 17$ & $7 / 17$ & $3 / 11$ & $4 / 10$ & $4 / 11$ & $5 / 11$ \\
\hline & $14-20$ & $4 / 8$ & $4 / 8$ & $4 / 8$ & $6 / 8$ & $3 / 5$ & $3 / 5$ & $3 / 5$ & $4 / 5$ \\
\hline & $21-27$ & $6 / 6$ & $5 / 5$ & $6 / 6$ & $6 / 6$ & $3 / 3$ & $3 / 3$ & $3 / 3$ & $3 / 3$ \\
\hline & $28-55$ & $10 / 10$ & $10 / 10$ & $10 / 10$ & $10 / 10$ & $4 / 4$ & $4 / 4$ & $4 / 4$ & $4 / 4$ \\
\hline & $1 \mathrm{y}$ & $4 / 4$ & $4 / 4$ & $4 / 4$ & $2 / 4$ & $4 / 4$ & $4 / 4$ & $4 / 4$ & $2 / 4$ \\
\hline \multirow[t]{5}{*}{ Died } & $<14$ & $9 / 11$ & $8 / 11$ & $5 / 11$ & $8 / 11$ & $5 / 6$ & $5 / 6$ & $3 / 6$ & $4 / 6$ \\
\hline & 14-20 & 9/9 & $6 / 8$ & $7 / 9$ & $9 / 9$ & $4 / 4$ & $2 / 3$ & $4 / 4$ & $4 / 4$ \\
\hline & $21-27$ & $9 / 9$ & $8 / 9$ & $8 / 9$ & $9 / 9$ & $4 / 4$ & $4 / 4$ & $4 / 4$ & $4 / 4$ \\
\hline & $28-55$ & $4 / 4$ & $4 / 4$ & $4 / 4$ & $4 / 4$ & $3 / 3$ & $3 / 3$ & $3 / 3$ & $3 / 3$ \\
\hline & $1 \mathrm{y}$ & NA & NA & NA & NA & NA & NA & NA & NA \\
\hline †Number & re not te & VSV & pseud & ssay & & & & & $\begin{array}{l}\text { LISA, } \\
\text { ods. }\end{array}$ \\
\hline
\end{tabular}

from South Korea $(5,45-47)$ in 2015 , and its association with increased severity in that setting was less clear $(5,45)$. In our investigation, factors affecting DM management before infection were unknown.

Information about MERS-CoV detection and antibody responses in case-patients who died has been limited $(19,24-26,29)$. In our study, patients who died had robust neutralizing antibody responses during the second and third weeks of illness, but this response was not sufficient for patient recovery. During this same period (weeks 2-3), RNA levels peaked in the LRT of these case-patients, suggesting that antibodies might not be sufficient for virus clearance. Antibodies were more often co-detected with viral RNA in the serum and URT of case-patients who died compared with survivors. Co-detection of antibodies and RNA has been described previously but not by patient outcome $(19,25)$. Six patients who died had MERS-CoV RNA in their serum, despite the presence of neutralizing antibodies, and 3 had RNA in urine. Detection of MERS-CoV in blood or serum has previously been associated with need for supplemental oxygen (18), the need for mechanical ventilation (24), and death $(24,26)$. Although we detected RNA in the blood or serum of all severity groups, estimated viral loads might have been higher in patients who died than survivors; this was difficult to assess statistically because of limited specimen collection and variability in timing of collection. In 4/12 patients who died, RNA levels in the LRT decreased to low or undetectable before death, suggesting that viral replication in the respiratory tract might variably or indirectly contribute to outcome.

Previous studies using MN tests (19) or S-specific assays $(25,31)$ have suggested that some case-patients who die might exhibit a delayed MERS-CoV-specific antibody response. Although most patients in our study developed early and concomitant MN and VSV-MERS-S (pseudoparticle assays) responses, 1 case-patient who died exhibited a prominent delay in detectable VSV-MERS-S and S ELISA responses compared with MN. This finding warrants further investigation and might suggest that the MN assay targets antibodies functioning beyond S-specific viral entry. Although our neutralizing assays targeted 2 different MERS-CoV strains, no variations exist within the receptor binding sites of these viruses (Appendix 1 Figure 10). Compared with these 2 viruses, the virus strain used in our S ELISA (EMC) differs in S by 2-3 aa, which is unlikely to confer a notable difference in binding during a polyclonal antibody response.

We further characterized virus shedding among mildly ill patients (i.e., those who did not require supplemental oxygen while hospitalized and who might typically be isolated at home) and found that RNA levels in the URT peaked during the first week of illness among this group, not in the second week as previously suggested (18), although LRT specimens were not available for included patients. Similar to previous descriptions, we detected MERS-CoV RNA in the blood or serum of some mildly ill patients $(18,25)$, but we also detected RNA in stool up to 15 days after illness onset; viable virus was not isolated from these specimen types. MERS-CoV RNA has been reported in stool previously (19), but the severity of illness and the time since illness onset in these patients were unknown. Replication in the intestinal tract has been postulated (27), but its role in pathogenesis or transmission remains unclear.

We characterized symptom progression in mildly symptomatic patients and found that fever and cough (when present) typically aligned with MERS-CoV detection. However, some patients remained febrile or reported cough even after virus clearance from the URT. Given the variability we observed in symptom progression during the MERS-CoV detection period, testing for viral shedding should continue to inform patient management, as stated in current World Health Organization guidance (14).

Our investigation has several limitations. First, the number of patients enrolled might have been insufficient to detect some associations, especially when adjusting for other variables. Second, testing data were not 
available before onset for all but 1 patients, and so we used days from onset to MERS-CoV negativity to assess shedding duration; we also excluded fatal cases from such analyses because time to death was not reflective of shedding duration, meaning that factors associated predominantly with mortality were not assessed for prolonged shedding. Third, the presence of MERS-CoV RNA does not necessarily represent viable

Survived

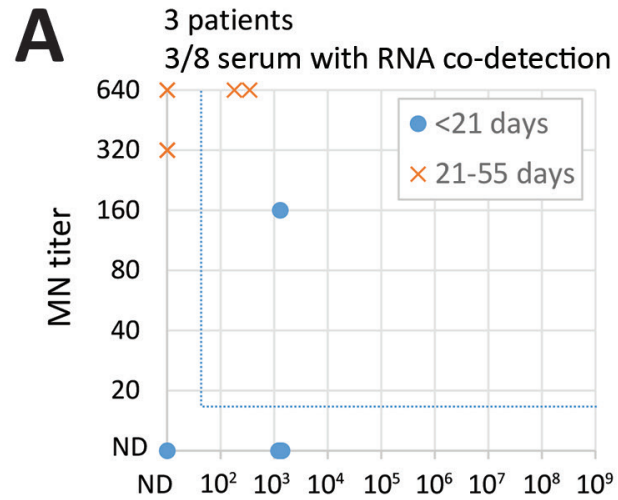

Estimated serum viral load

B

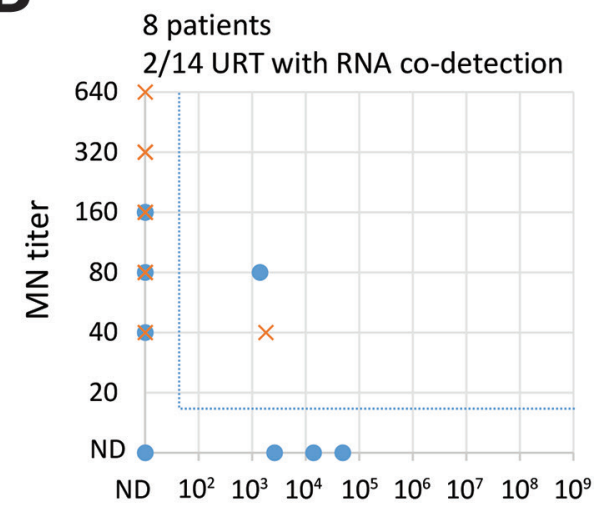

Estimated serum viral load



Estimated serum viral load

virus. Fourth, serum specimen collection was deemed too sparse to reliably assess antibody kinetics at the patient level.

Prolonged shedding in those with DM and the detection of MERS-CoV RNA from nonrespiratory specimens, including RNA-positive stool in mildly ill patients, should be considered in infection prevention and control and when determining whether home isolation is appropriate. The

\section{Died}

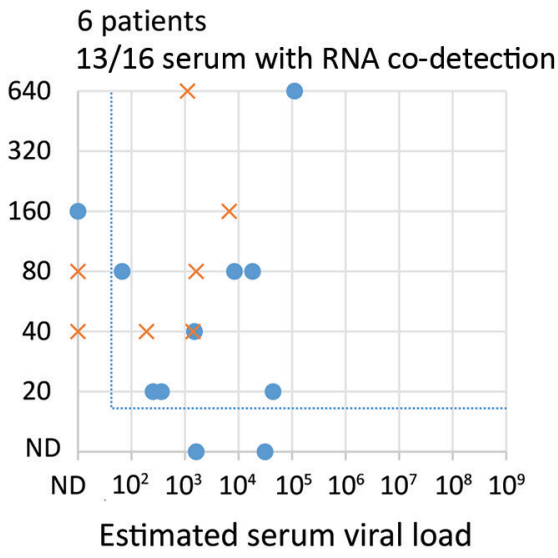

9 patients

11/16 URT with RNA co-detection
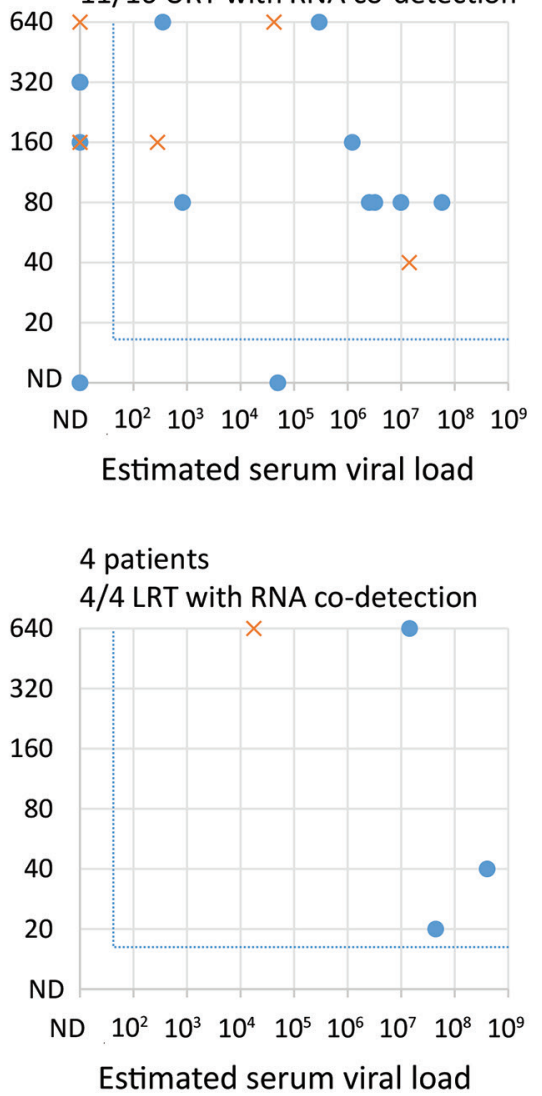

Figure 6. Co-detection of neutralizing serum antibodies with RNA found in serum and the upper and lower respiratory tracts among Middle East respiratory syndrome patients, by clinical outcome, Saudi Arabia, August 1, 2015-August 31, 2016. For each patient and specimen, MN titers of serum specimens were compared with estimated viral loads in the same serum specimen $(A)$ or in URT (B) and LRT (C) specimens collected on the same day from the same patient. We defined RNA codetection as the detection of both RNA and neutralizing antibodies (MN) in the same specimen or in respiratory specimens collected on the same day from a given patient. We only included specimens from patients who were known to develop neutralizing antibodies at any point during or after their illness. For the comparison in serum specimens, we only included specimens from patients who were known to have RNA detected in serum, at any point during their illness. For each panel, the number of patients included are indicated above the panel. The number of specimens with RNA co-detection (indicated by $\mathrm{X}$ ) among those with detectable antibodies (indicated by $Y)$ are also indicated by numbers $(\mathrm{X} / \mathrm{Y})$ above each panel. The blue dotted lines indicate the detection cut-offs for each assay. LRT, lower respiratory tract; ND, not detected; $\mathrm{MN}$, microneutralization assay; URT, upper respiratory tract. 
presence of detectable antibodies in case-patients who died and the co-detection of antibodies with viral RNA might also have implications for the development of vaccines and antibody therapeutics. Our findings broaden our understanding of MERS-CoV natural history and provide evidence to inform surveillance strategies, diagnostics, therapeutic and vaccine development, and clinical and public health management guidelines for MERS patients.

\section{Acknowledgments}

We thank Holly M. Biggs for critical review of the manuscript, Shifaq Kamili for specimen coordination, and Melvina Girvan for assistance with data collection.

This work was funded by the Ministry of Health in Saudi Arabia, and the US Centers for Disease Control and Prevention.

The study was reviewed and approved by the Saudi Arabia Ministry of Health institutional review board. Because CDC only had access to deidentified data for secondary analyses, it was determined this project was not human subjects research, and therefore CDC's institutional review board approval was not required.

\section{About the Author}

During this investigation, Dr. Al-Abdely was general director of Infection Prevention and Control, Ministry of Health, Saudi Arabia. He currently is professor of medicine at Alfaisal University, Saudi Arabia, and a consultant in infectious diseases for King Faisal Specialist Hospital and Research Centre, Saudi Arabia. His research interests include infection prevention and control, medical mycology, and microbial resistance.

\section{References}

1. Assiri A, McGeer A, Perl TM, Price CS, Al Rabeeah AA, Cummings DA, et al.; KSA MERS-CoV Investigation Team. Hospital outbreak of Middle East respiratory syndrome coronavirus. N Engl J Med. 2013;369:407-16. http://dx.doi.org/ 10.1056/NEJMoa1306742

2. Oboho IK, Tomczyk SM, Al-Asmari AM, Banjar AA, Al-Mugti H, Aloraini MS, et al. 2014 MERS-CoV outbreak in Jeddah-a link to health care facilities. N Engl J Med. 2015;372:846-54. http://dx.doi.org/10.1056/NEJMoa1408636

3. Arabi YM, Al-Omari A, Mandourah Y, Al-Hameed F, Sindi AA, Alraddadi B, et al.; Saudi Critical Care Trial Group. Critically ill patients with the Middle East respiratory syndrome: a multicenter retrospective cohort study. Crit Care Med. 2017;45:1683-95. http://dx.doi.org/10.1097/CCM.0000000000002621

4. Arabi YM, Balkhy HH, Hayden FG, Bouchama A, Luke T, Baillie JK, et al. Middle East respiratory syndrome. N Engl J Med. 2017;376:584-94. http://dx.doi.org/10.1056/NEJMsr1408795

5. Ko JH, Park GE, Lee JY, Lee JY, Cho SY, Ha YE, et al. Predictive factors for pneumonia development and progression to respiratory failure in MERS-CoV infected patients. J Infect. 2016;73:468-75. http://dx.doi.org/10.1016/j.jinf.2016.08.005

6. Senga M, Arabi YM, Fowler RA. Clinical spectrum of the Middle East respiratory syndrome coronavirus (MERS-CoV). J Infect Public Health. 2017;10:191-4. http://dx.doi.org/10.1016/ j.jiph.2016.04.008
7. Assiri A, Al-Tawfiq JA, Al-Rabeeah AA, Al-Rabiah FA, Al-Hajjar S, Al-Barrak A, et al. Epidemiological, demographic, and clinical characteristics of 47 cases of Middle East respiratory syndrome coronavirus disease from Saudi Arabia: a descriptive study. Lancet Infect Dis. 2013;13:752-61. http://dx.doi.org/ 10.1016/S1473-3099(13)70204-4

8. Saad M, Omrani AS, Baig K, Bahloul A, Elzein F, Matin MA, et al. Clinical aspects and outcomes of 70 patients with Middle East respiratory syndrome coronavirus infection: a single-center experience in Saudi Arabia. Int J Infect Dis. 2014;29:301-6. http://dx.doi.org/10.1016/j.ijid.2014.09.003

9. World Health Organization. Middle East respiratory syndrome coronaviurs (MERS-CoV) fact sheet [cited 2017 Oct 30]. https://www.who.int/en/news-room/fact-sheets/detail/middle-eastrespiratory-syndrome-coronavirus-(mers-cov)

10. Assiri AM, Biggs HM, Abedi GR, Lu X, Bin Saeed A, Abdalla O, et al. Increase in Middle East Respiratory syndrome-coronavirus cases in Saudi Arabia linked to hospital outbreak with continued circulation of recombinant virus, July 1-August 31, 2015. Open Forum Infect Dis. 2016;3:ofw165.

11. Assiri A, Abedi GR, Bin Saeed AA, Abdalla MA, al-Masry M, Choudhry AJ, et al. Multifacility outbreak of Middle East respiratory syndrome in Taif, Saudi Arabia. Emerg Infect Dis. 2016;22:32-40. http://dx.doi.org/10.3201/eid2201.151370

12. Drosten C, Meyer B, Müller MA, Corman VM, Al-Masri M, Hossain R, et al. Transmission of MERS-coronavirus in household contacts. N Engl J Med. 2014;371:828-35. http://dx.doi.org/10.1056/NEJMoa1405858

13. Alraddadi BM, Watson JT, Almarashi A, Abedi GR, Turkistani A, Sadran M, et al. Risk factors for primary Middle East respiratory syndrome coronavirus illness in humans, Saudi Arabia, 2014. Emerg Infect Dis. 2016;22:49-55. http://dx.doi.org/10.3201/ eid2201.151340

14. World Health Organization. Infection prevention and control during health care for probable or confirmed cases of Middle East respiratory syndrome coronavirus (MERS-CoV) infection - interim guidance [cited 2017 Oct 30]. https://www.who.int/csr/disease/ coronavirus_infections/ipc-mers-cov/en

15. World Health Organization. Management of asymptomatic persons who are RT-PCR positive for Middle East respiratory syndrome coronavirus (MERS-CoV) [cited 2018 Sep 20]. https://www.who. $\mathrm{int} / \mathrm{csr} /$ disease/coronavirus_infections/management_of_ asymptomatic_patients/en

16. Memish ZA, Assiri AM, Al-Tawfiq JA. Middle East respiratory syndrome coronavirus (MERS-CoV) viral shedding in the respiratory tract: an observational analysis with infection control implications. Int J Infect Dis. 2014;29:307-8. http://dx.doi.org/ 10.1016/j.ijid.2014.10.002

17. Poissy J, Goffard A, Parmentier-Decrucq E, Favory R, Kauv M, Kipnis E, et al.; MERS-CoV Biology Group. Kinetics and pattern of viral excretion in biological specimens of two MERS-CoV cases. J Clin Virol. 2014;61:275-8. http://dx.doi.org/10.1016/ j.jcv.2014.07.002

18. Oh MD, Park WB, Choe PG, Choi SJ, Kim JI, Chae J, et al. Viral load kinetics of MERS coronavirus infection. N Engl J Med. 2016;375:1303-5. http://dx.doi.org/10.1056/ NEJMc1511695

19. Corman VM, Albarrak AM, Omrani AS, Albarrak MM, Farah ME, Almasri M, et al. Viral shedding and antibody response in 37 patients with Middle East respiratory syndrome coronavirus infection. Clin Infect Dis. 2016;62:477-83.

20. Memish ZA, Al-Tawfiq JA, Makhdoom HQ, Assiri A, Alhakeem RF, Albarrak A, et al. Respiratory tract samples, viral load, and genome fraction yield in patients with Middle East respiratory syndrome. J Infect Dis. 2014;210:1590-4. http://dx.doi.org/10.1093/infdis/jiu292 
21. Feikin DR, Alraddadi B, Qutub M, Shabouni O, Curns A, Oboho IK, et al. Association of higher MERS-CoV virus load with severe disease and death, Saudi Arabia, 2014. Emerg Infect Dis. 2015;21:2029-35. http://dx.doi.org/10.3201/eid2111.150764

22. Guery B, Poissy J, el Mansouf L, Séjourné C, Ettahar N, Lemaire X, et al.; MERS-CoV study group. Clinical features and viral diagnosis of two cases of infection with Middle East respiratory syndrome coronavirus: a report of nosocomial transmission. Lancet. 2013;381:2265-72. http://dx.doi.org/10.1016/ S0140-6736(13)60982-4

23. Drosten C, Seilmaier M, Corman VM, Hartmann W, Scheible G, Sack S, et al. Clinical features and virological analysis of a case of Middle East respiratory syndrome coronavirus infection. Lancet Infect Dis. 2013;13:745-51. http://dx.doi.org/10.1016/ S1473-3099(13)70154-3

24. Kim SY, Park SJ, Cho SY, Cha RH, Jee HG, Kim G, et al. Viral RNA in blood as indicator of severe outcome in Middle East respiratory syndrome coronavirus infection. Emerg Infect Dis. 2016;22:1813-6. http://dx.doi.org/10.3201/eid2210.160218

25. Min CK, Cheon S, Ha NY, Sohn KM, Kim Y, Aigerim A, et al. Comparative and kinetic analysis of viral shedding and immunological responses in MERS patients representing a broad spectrum of disease severity. Sci Rep. 2016;6:25359. http://dx.doi.org/10.1038/srep25359

26. Shalhoub S, Farahat F, Al-Jiffri A, Simhairi R, Shamma O, Siddiqi N, et al. IFN- $\alpha 2$ a or IFN- $\beta 1$ a in combination with ribavirin to treat Middle East respiratory syndrome coronavirus pneumonia: a retrospective study. J Antimicrob Chemother. 2015;70:2129-32. http://dx.doi.org/10.1093/jac/dkv085

27. Zhou J, Li C, Zhao G, Chu H, Wang D, Yan HH, et al. Human intestinal tract serves as an alternative infection route for Middle East respiratory syndrome coronavirus. Sci Adv. 2017;3:eaao4966.

28. Choe PG, Perera RAPM, Park WB, Song KH, Bang JH, Kim ES, et al. MERS-CoV antibody responses 1 year after symptom onset, South Korea, 2015. Emerg Infect Dis. 2017;23:1079-84. http://dx.doi.org/10.3201/eid2307.170310

29. Shin HS, Kim Y, Kim G, Lee JY, Jeong I, Joh JS, et al. Immune responses to MERS coronavirus during the acute and convalescent phases of human infection. Clin Infect Dis. 2018. http://dx.doi.org/10.1093/cid/ciy595

30. Park WB, Perera RA, Choe PG, Lau EH, Choi SJ, Chun JY, et al. Kinetics of serologic responses to MERS coronavirus infection in humans, South Korea. Emerg Infect Dis. 2015;21:2186-9. http://dx.doi.org/10.3201/eid2112.151421

31. Ko JH, Müller MA, Seok H, Park GE, Lee JY, Cho SY, et al. Serologic responses of 42 MERS-coronavirus-infected patients according to the disease severity. Diagn Microbiol Infect Dis. 2017;89:106-11. http://dx.doi.org/10.1016/j.diagmicrobio.2017.07.006

32. Payne DC, Iblan I, Rha B, Alqasrawi S, Haddadin A, Al Nsour $\mathrm{M}$, et al. Persistence of antibodies against Middle East respiratory syndrome coronavirus. Emerg Infect Dis. 2016;22:1824-6. http://dx.doi.org/10.3201/eid2210.160706

33. Saeed AA, Abedi GR, Alzahrani AG, Salameh I, Abdirizak F, Alhakeem R, et al. Surveillance and testing for Middle East respiratory syndrome coronavirus, Saudi Arabia, April 2015February 2016. Emerg Infect Dis. 2017;23:682-5.

http://dx.doi.org/10.3201/eid2304.161793

34. Corman VM, Ölschläger S, Wendtner CM, Drexler JF, Hess M, Drosten C. Performance and clinical validation of the RealStar MERS-CoV kit for detection of Middle East respiratory syndrome coronavirus RNA. J Clin Virol. 2014;60:168-71. http://dx.doi.org/10.1016/j.jcv.2014.03.012

35. Lu X, Whitaker B, Sakthivel SK, Kamili S, Rose LE, Lowe L, et al. Real-time reverse transcription-PCR assay panel for Middle East respiratory syndrome coronavirus. J Clin Microbiol. 2014;52:6775. http://dx.doi.org/10.1128/JCM.02533-13

36. Al-Abdely HM, Midgley CM, Alkhamis AM, Abedi GR, Tamin A, Binder AM, et al. Infectious MERS-CoV isolated from a mildly ill patient, Saudi Arabia. Open Forum Infect Dis. 2018;5:ofy111. http://dx.doi.org/10.1093/ofid/ofy111

37. Al-Abdallat MM, Payne DC, Alqasrawi S, Rha B, Tohme RA, Abedi GR, et al.; Jordan MERS-CoV Investigation Team. Hospital-associated outbreak of Middle East respiratory syndrome coronavirus: a serologic, epidemiologic, and clinical description. Clin Infect Dis. 2014;59:1225-33. http://dx.doi.org/10.1093/cid/ciu359

38. Trivedi S, Miao C, Al-Abdallat MM, Haddadin A, Alqasrawi S, Iblan I, et al. Inclusion of MERS-spike protein ELISA in algorithm to determine serologic evidence of MERS-CoV infection. J Med Virol. 2018;90:367-71. http://dx.doi.org/10.1002/jmv.24948

39. Assiri AM, Midgley CM, Abedi GR, Bin Saeed A, Almasri MM, Lu X, et al. Epidemiology of a novel recombinant Middle East respiratory syndrome coronavirus in humans in Saudi Arabia.J Infect Dis. 2016;214:712-21. http://dx.doi.org/10.1093/infdis/jiw236

40. Sabir JS, Lam TT, Ahmed MM, Li L, Shen Y, Abo-Aba SE, et al. Co-circulation of three camel coronavirus species and recombination of MERS-CoVs in Saudi Arabia. Science. 2016;351:81-4. http://dx.doi.org/1W0.1126/science.aac8608

41. World Health Organization. Diabetes country profile, Saudi Arabia [cited 2017 Dec 26]. https://www.who.int/diabetes/country-profiles/ sau_en.pdf

42. International Diabetes Federation. Age-adjusted prevalence of diabetes (20-79), Saudi Arabia, 2017 [cited 2017 Dec 26]. http://www.diabetesatlas.org/across-the-globe.html

43. Badawi A, Ryoo SG. Prevalence of diabetes in the 2009 influenza A (H1N1) and the Middle East respiratory syndrome coronavirus: a systematic review and meta-analysis. J Public Health Res. 2016;5:733. http://dx.doi.org/10.4081/jphr.2016.733

44. Banik GR, Alqahtani AS, Booy R, Rashid H. Risk factors for severity and mortality in patients with MERS-CoV: analysis of publicly available data from Saudi Arabia. Virol Sin. 2016;31:81-4. http://dx.doi.org/10.1007/s12250-015-3679-z

45. Choi WS, Kang CI, Kim Y, Choi JP, Joh JS, Shin HS, et al.; Korean Society of Infectious Diseases. Clinical presentation and outcomes of Middle East respiratory syndrome in the Republic of Korea. Infect Chemother. 2016;48:118-26. http://dx.doi.org/10.3947/ ic.2016.48.2.118

46. Kim ES, Choe PG, Park WB, Oh HS, Kim EJ, Nam EY, et al. Clinical progression and cytokine profiles of Middle East respiratory syndrome coronavirus infection. J Korean Med Sci. 2016;31:1717-25. http://dx.doi.org/10.3346/jkms.2016.31.11.1717

47. Kim KH, Tandi TE, Choi JW, Moon JM, Kim MS. Middle East respiratory syndrome coronavirus (MERS-CoV) outbreak in South Korea, 2015: epidemiology, characteristics and public health implications. J Hosp Infect. 2017;95:207-13. http://dx.doi.org/ 10.1016/j.jhin.2016.10.008

Address for correspondence: Claire M. Midgley or John T. Watson, Centers for Disease Control and Prevention, 1600 Clifton Road NE, Atlanta, GA, 30329-4027; email: ydk5@cdc.gov or acq4@cdc.gov 